\title{
COASTAL HABITATS WITHIN FLOOD RISK ASSESSMENTS: ROLE OF THE 2D SPR APPROACH
}

\author{
Siddharth Narayan ${ }^{1}$, Robert J, Nicholls ${ }^{1}$, Ekaterina Trifonova ${ }^{2}$, Mariana Filipova - Marinova ${ }^{3}$, \\ Iliyan Kotsev ${ }^{2}$, Stoyan Vergiev ${ }^{3}$, Susan Hanson ${ }^{1}$, Derek Clarke ${ }^{1}$ \\ Coastal habitats are highly threatened ecosystems that are sensitive to complex sets of natural and human drivers. \\ Europe's coastal habitats are protected from damage due to human activity by the EU Habitats Directive, and are \\ required to be mapped within flood risk assessments by the EU Floods Directive. Ecological vulnerability and risk \\ assessments are a common way of assessing the impacts on these habitats due to human and natural drivers. Coastal \\ flood risk assessments therefore often include assessments of the vulnerability of coastal habitats. Flood risk \\ assessments also evaluate, where relevant, the mitigation services provided by coastal habitats. The two aspects of \\ coastal habitats - their flood mitigation service and their ecological vulnerability are strongly correlated; however \\ these are usually treated separately within flood risk assessments. One of the goals of the EU THESEUS project is the \\ integrated consideration of coastal habitats within flood risk assessments. This paper investigates the integration \\ within flood risk assessments of the two aspects of coastal habitats using the 2D SPR conceptual model. The \\ construction of the model is first illustrated by application to a generic study site. The model is then applied to a case- \\ study where data on habitat elevations and vulnerabilities to flood events have been collected. The model provides a \\ unique and robust means of combining information on ecological vulnerability indices for different habitat \\ associations with information on their distribution and spatial relationships within the coastal floodplain. Used in \\ conjunction with information on habitat vulnerability indices, the conceptual model serves as a powerful tool for \\ integrated and structured consideration of coastal habitats within flood risk assessments.
}

Keywords: coastal habitats, flood risk, 2D SPR, integrated assessments, Habitats Directive, Floods Directive

\section{INTRODUCTION}

At 112 persons $/ \mathrm{km} 2$, the average density of population in the near-coastal zones is nearly three times the global average (Small and Nicholls, 2003). Coastal zones also contain some of the world's most diverse and valuable habitats (Edgar et al., 2000; Suchanek, 1994). The concentration of human population along coastlines means that coastal habitats are some of the most stressed ecosystems on Earth (Airoldi and Beck, 2007; Lotze et al., 2006). Coastal habitats are affected by a variety of human activities from local and regional scale land transformation to larger scale increases in $\mathrm{CO} 2$ content and the alteration of biogeochemical cycles and biotic processes(Airoldi and Beck, 2007; Vitousek et al., 1997). The preservation and enhancement of coastal habitats is increasingly being considered in terms of the total ecosystem services they provide rather than just their ecological uniqueness or rarity (EEA, 2010b)

The twin problems of coastal erosion and flooding are set to become even more serious due to ongoing sea-level rise as a result of local subsidence and global warming of sea temperatures (Airoldi and Beck, 2007). For coastal wetlands, flood prevention and buffering is an ecosystem service that is strongly linked to the biodiversity and health of the wetland habitats within the ecosystem (EEA, 2010b). The collapse and degradation of these habitats can potentially have disastrous impacts, as has been argued in the Asian tsunami of 2004 and Hurricane Katrina in 2005 (Adger et al., 2005; Danielsen et al., 2005). Responsible for $64 \%$ of all change to Europe's coastal habitats, coastal erosion is the major driver affecting these habitats (EEA 2010). At present more than $15000 \mathrm{~km}$ of European coastlines face the threat of erosion. Erosion mitigation schemes that have been put in place to tackle the problem of coastal erosion have often resulted in widespread and dramatic changes to natural coastal habitats due to limitation of changes in sediment supplies (Airoldi et al., 2005; EC, 2004). Between 1990 and 2006, 0.75 to $0.82 \%$ of European coastal zones have been built up into artificial surfaces (EEA, 2010a). Planning and management of these problems however need to consider coastal habitats not just in terms of their impact on human development, but also in terms of the ecological impacts of any human activity. It is therefore essential to be able to integrate information and knowledge between flood risk assessments on the one hand and the ecological health of coastal habitats on the other.

The flood prevention and buffering service provided by coastal habitats is a widely researched topic (e.g., Alongi 2002, Moller 2006, Tanaka et al., 2007). However information and knowledge from these studies is rarely integrated with studies that assess the ecological vulnerability of coastal habitats to short term drivers such as floods and long-term drivers such as coastal erosion or human activity. Recent European flood risk assessment studies (e.g., Evans et al., 2004, FLOODSite, 2009) recognise the systems nature of coastal floodplains, especially with regard to coastal habitats and their

${ }^{1}$ Faculty of Engineering and the Environment, University of Southampton, Southampton, SO17 1BJ UK

${ }^{2}$ Institute of Oceanology, Bulgarian Academy of Science, Varna, Bulgaria

${ }^{3}$ Museum of Natural History, Bulgarian Academy of Science, Varna, Bulgaria 
relationship with other floodplain elements. The EU Habitats Directive (92/43/EEC) (The European Commission, 2007a) recognises the importance of coastal habitats in terms of their ecological value and requires that coastal habitats are managed to maintain and if possible enhance their physical extents. If successful, this can contribute significantly to the flood mitigation service provided by these habitats. The EU Floods Directive (2007/60/EC) recognises the significance of coastal habitats within flood risk studies and requires member states to map all assets that are at risk of flooding. This includes habitats that are at direct risk of flooding, or that may be affected by knock-on effects such as pollution from flooded installations (The European Commission, 2007b). However, the role of coastal habitats is not always appreciated or considered in flood risk management (THESEUS Consortium, 2012b). The main challenge to achieving integration of both aspects of coastal habitats within coastal floodplain studies is the difference in the habitat properties that are assessed - the 'roughness factor' (e.g. King \& Lester 1995, Moller 1996), 'erosion mitigation' (e.g., Woodhouse et al., 1976, Meyer et al., 1997) or storage capacity of a coastal habitat (e.g., Mitch and Gosselink, 2000, Acreman et al., 2007) when evaluating the flood buffering provided; plant health, habitat productivity, diversity and extent when estimating short and long-term ecological vulnerabilities (e.g. McFadden et al., 2007, Friess et al., 2012).

The THESEUS project (www.theseusproject.eu) aims to deliver safer European coasts from the perspective of coastal flooding for human and natural assets. With regard to coastal habitats, the THESEUS project aims to a) include the role of coastal habitats within flood risk assessments and; b) consider the vulnerability of coastal habitats to coastal flooding. A descriptive yet flexible conceptual platform is necessary to be able to integrate information and knowledge between flood risk assessments on the one hand and the ecological health of coastal habitats on the other.

This paper presents a conceptual model for integrating information on both these aspects of flood risk assessments. The conceptual model applied here is the 2D SPR (Source - Pathway - Receptor) SPR model. Derived from a systems approach to coastal floodplains and built iteratively by the users, the model highlights the spatial connectivity and possible inter-linkages between discrete floodplain elements. The SPR approach is described using a generic case-study. The model is applied to a coastal flood system on the Black Sea Coast in Bulgaria with the aim of presenting information on habitat vulnerabilities and flood risk on a single platform.. It provides a platform for understanding and evaluating the relationships between these habitats and the rest of the coastal flood system.

\section{D SPR CONCEPTUAL MODEL}

The Source - Pathway - Receptor (SPR) model is a popular conceptual framework in coastal flooding that provides a linear representation of the physical processes of flooding (Evans et al., 2004; FLOODSite Consortium, 2009). The SPR model has been adopted from environmental pollution where it was widely used to evaluate risks arising from leakage of toxic pollutants. The main premise of the model is that the propagation of a flood event and the associated risk can be schematized in terms of a source for the event, a receptor and a pathway by which the event reaches the receptor. A 'Consequence' component is often added to the model that facilitates evaluation of impacts for different events and receptors.

Flood risk assessments and models however require a variety of data and inputs from different types floodplain elements that are often spatially distributed. The conceptual description of the floodplain within the SPR is aggregated into a linear, 1D representation which is inadequate for describing large and complex floodplains. The 1D approach has therefore been extended to a $2 \mathrm{D}$ systems model that provides a more comprehensive picture of the floodplain and its elements. The 2D SPR is constructed by the users by an iterative process and allows improved representation of specific floodplain elements such as coastal habitats (Narayan et al., 2012).

\section{Generic Implementation}

The 2D SPR model is implemented in four steps:

Step 1: Identification of floodplain boundaries based on planar water level model, assuming worst-case flood event and absence of structural defences.

Step 2: Mapping and land-use classification of individual elements within floodplain by model users and stakeholders. Any element can be represented regardless of its size or resolution (Fig 2).

Step 3: Drawing of system diagram by schematisation of land-use map and identification of links between elements - any two elements within the floodplain that share a geographical boundary are assumed to share a link (Fig 3).

Step 4: Identification and linking of sources to floodplain system diagram. 
Steps 2-4 of the process are repeated until consensus is reached among all users regarding completeness of the model. In this way a comprehensive map of the natural floodplain is obtained that includes all elements under consideration across the range of interested stakeholders.

A sample 2D SPR is first built for a generic coastal floodplain following the steps above. Fig 1 describes the floodplain extent for a typical, generic coastline, along with mapped and classified landuse elements following Steps 1 and 2. Some elements such as the beach and the seawall in Fig 1 are of much smaller resolution compared to the other floodplain elements. Fig 2 indicates the SPR schematic prepared from the land-use map, where the elements are linked to one another and the source of flooding.

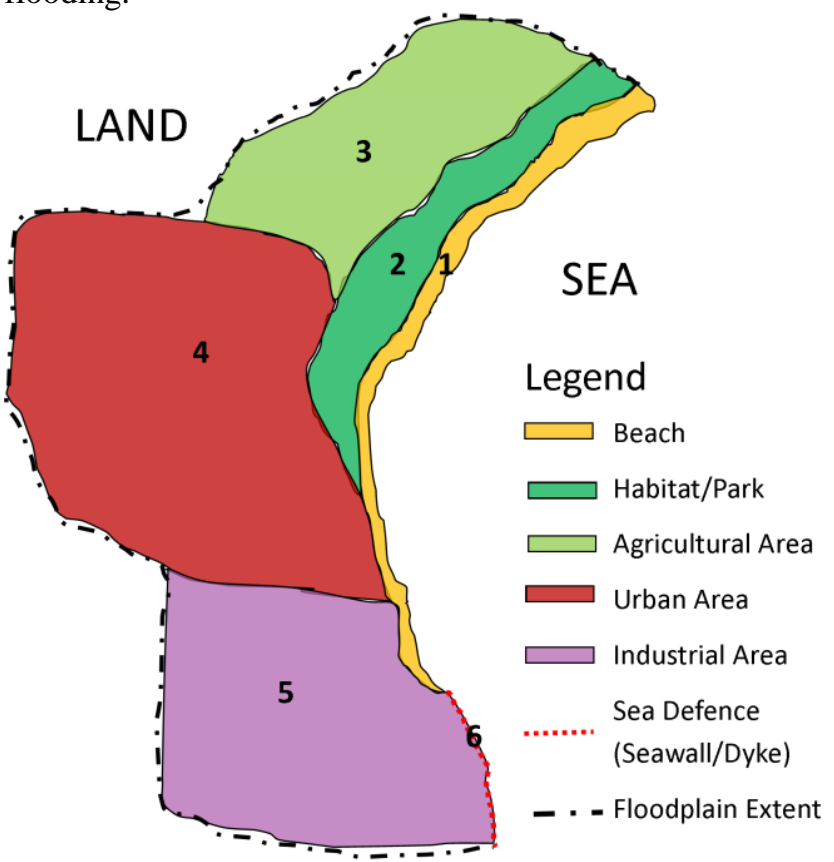

Figure 1: Generic coastline, land-use map and floodplain extent for illustration of 2D SPR construction (steps 1-2)

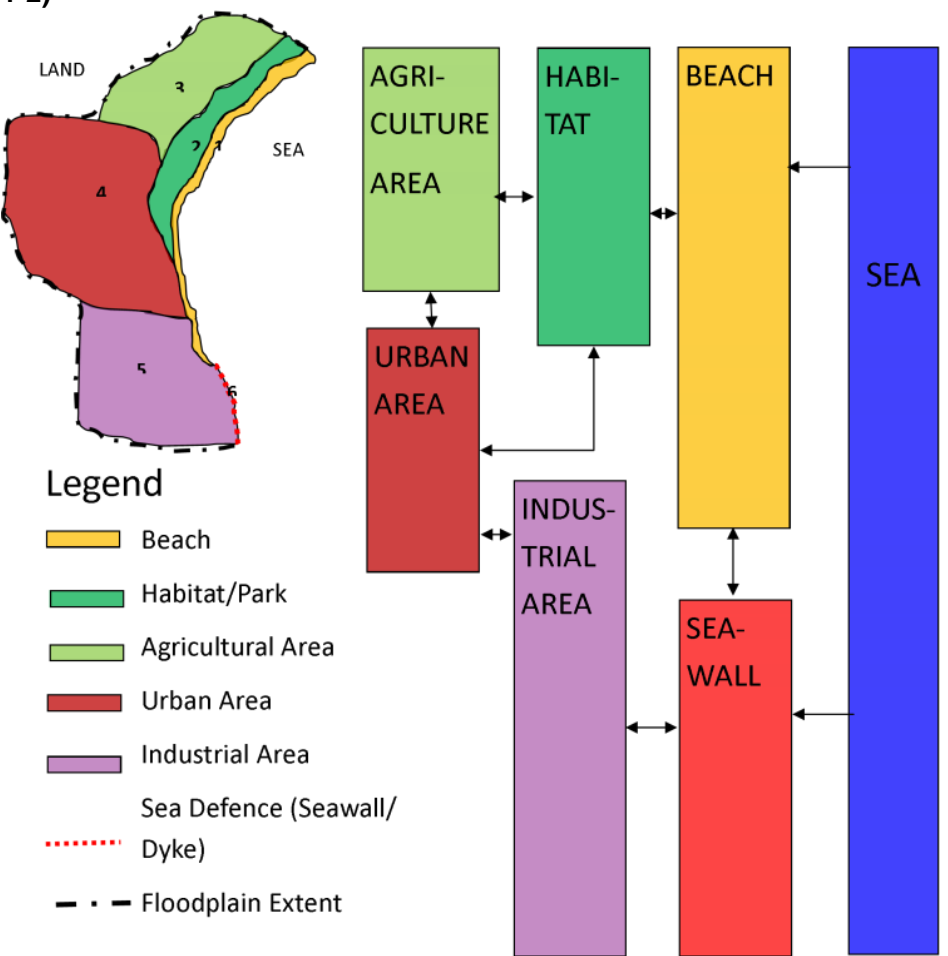

Figure 2: Generic example of 2D SPR systems model for floodplain system in Fig 1 
The 2D SPR in Fig 2 provides an immediate representation of the system linkages between different floodplain elements. In the case of large and complex floodplains, or when mapping elements of varying resolutions these linkages may not be obvious on a map. In such instances, a systems diagram of this type can serve as a quick and robust tool for qualitative floodplain descriptions.

\section{CONCEPTUAL MODEL: SITE APPLICATION}

\section{Study Area - Description}

The study area is part of the Varna coastal region, located on the Bulgarian Black Sea coast between Cape Ekrene and Cape Galata (Fig 3). The coastal areas in the region consist predominantly of beaches with several resorts. The region also contains the port and city of Varna. Within Varna Port, an $11 \mathrm{~m}$ deep dredged channel connects the Varna Lake to the Black Sea. Immediately south of the navigation channel are the Karantinata beach and Asparuhovo maritime park that form the southern boundary of the study area.

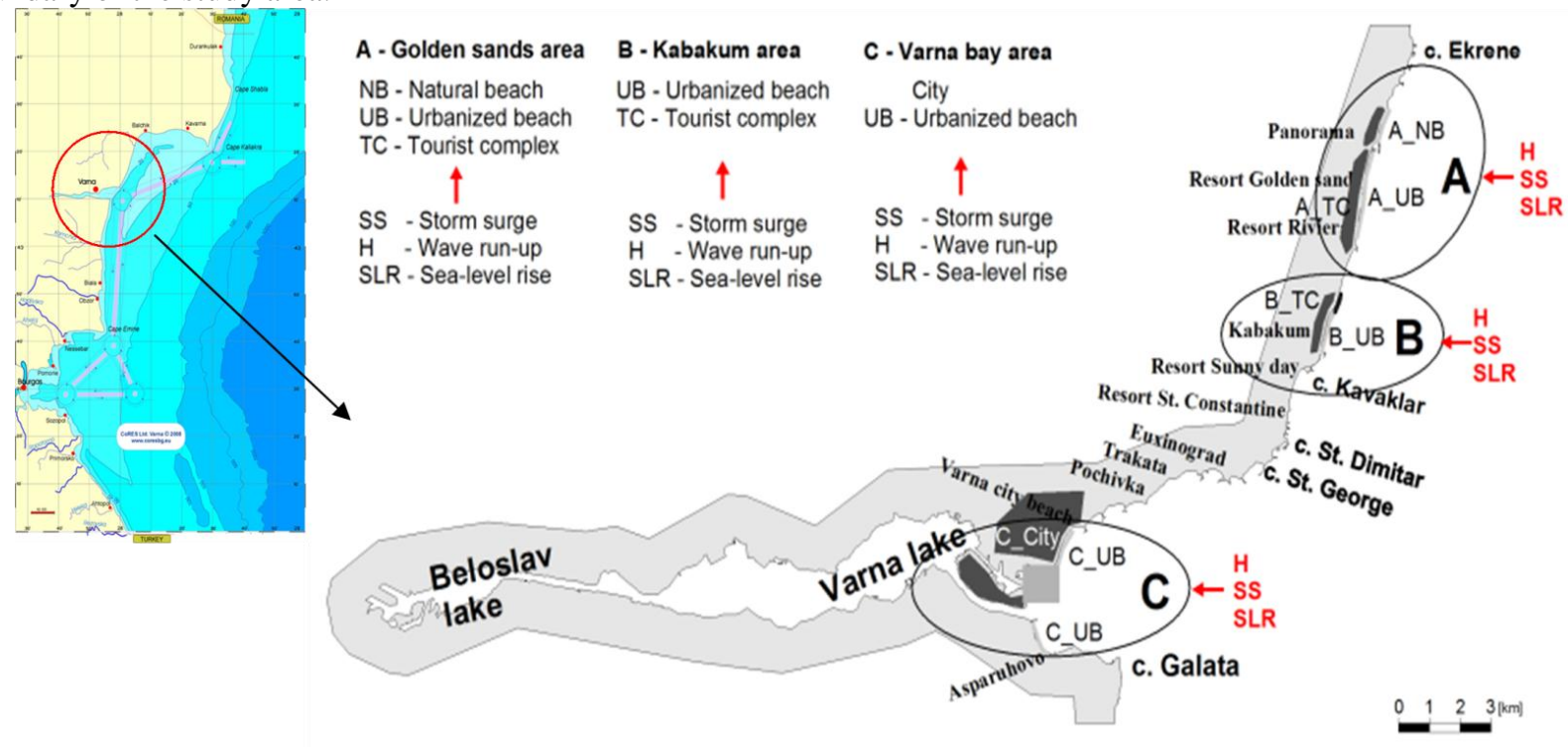

Figure 3: Study area (Area C) on Bulgarian Black Sea Coast (THESEUS Consortium, 2012b)

The Karantinata beach is a naturally occurring sheltered beach formation. The beach was eroded, and its length drastically reduced due to construction of the shipping channel in 1976. The beach shows significant shoreline recession in the last 100 years chiefly due to sustained human activity in the region (Stancheva et al., 2011). The beach is a good example of coastal sand strip habitats and lies within a Natura2000 protected site 'Galata BG0002060' according to the Birds Directive (Directive 2009/147/EC). The beach also contains habitats (designations: 1210, annual vegetation of drift lines; 2110, embryonic shifting dunes) listed within the EU Habitats Directive (Directive 92/43/EEC). The southern portion of the beach contains a few fishermen's houses and a number of temporary tourist structures. The beach is prone to flooding from storm surges with some of the houses being inundated during a storm in February 2012 (THESEUS Consortium, 2012a; THESEUS Consortium, 2012b). The habitats on this beach provide an important flood mitigation service by stabilising the beach against erosion during storms (THESEUS Consortium, 2012b).

As a combination of a sheltered beach with listed habitats and plant communities and a flood prone area, the Karantinata beach provides an interesting case-study to examine inter-relationships between different coastal elements. The 2D SPR application for the study area focuses on the Karantinata beach. The model provides a novel way of integrating information obtained from flood models with information on the vegetation communities found in the area.

\section{Study Area - Flood Mapping}

The Varna region, and the Karantinata beach in particular, are mostly tideless and have no large rivers. Thus the chief inundation risk for the Karantinata beach comes from a combination of storm waves and storm surges. The beach narrows in width from $100 \mathrm{~m}$ in the north to about $40 \mathrm{~m}$ in the south. Flood models indicate that for a 100 year return period storm from any direction, the northern portion of the beach will be flooded to a maximum of $50 \%$ of its width while the southern portion will always be entirely inundated. The southern portion of the beach, consisting mainly of fishing hamlets 
and temporary tourist structures is therefore extremely vulnerable to nearly all storms, regardless of wind direction(THESEUS Consortium, 2012b). The area was divided into a series of profiles, and information on flood elevation and flood duration obtained for each profile for a 100 year storm. This information was subsequently integrated with information on floodplain element elevations and distribution of vegetation communities.

\section{Study Area - Habitat and Vulnerability Mapping}

Sand strips are low-lying areas with the associated vegetation forming on sandy areas just above the Mean High Water Springs line (supratidal zone). Coastal sand strips form unique habitats, and the vicinity of the sea, and specific sand substrates are conducive to the growth of rare and endangered species of coastal vegetation (Table 1). The preservation of some species found in the region, such as Leymus racemosu,s ssp. sabulosus and Phragmites australis, also contribute to protection against storms (THESEUS Consortium, 2012b).

\begin{tabular}{|l|c|c|}
\hline \multicolumn{2}{|c|}{ Table 1. Threatened and rare species in the Karantinata Beach area } \\
\hline Name & $\begin{array}{l}\text { Biodiversity } \\
\text { law }\end{array}$ & $\begin{array}{l}\text { Bulgarian Red } \\
\text { Data Book / Rare }\end{array}$ \\
\hline Centaurea arenaria Bieb. ex Willd. & & $\mathrm{X}$ \\
\hline Eryngium maritimum L. & $\mathrm{X}$ & $\mathrm{X}$ \\
\hline Lactuca tatarica (L.) C.A.Mey & & $\mathrm{X}$ \\
\hline
\end{tabular}

During a storm these plant species may be affected by direct wave damage, or in case of long-term flooding, may undergo leaf, stem and root decomposition. In this study, the information presented in the 2D SPR model is limited to the effect of long-term flooding of vegetation communities within the flooded region.

To estimate the degree of vulnerability of these communities to storms data was collected on plant distributions on the beach and combined with data on the extent of flooding for different return periods. The degree of vulnerability was estimated in terms of rates of leaf, stem and root decomposition of the different communities. Manipulative experiments were conducted to identify the rates of decomposition of different communities to floods of different durations and the possibility for their regeneration (Vergiev et al., 2012). From these experiments information was obtained on the 'Critical Decomposition Times' (CDT) of each community. Since different communities can have different levels of vulnerability, the assessment was averaged across communities. Data collected in the field and processed in the laboratory were further integrated and analysed in a GIS environment using a Digital Terrain Model (DTM).

\section{Study Area - 2D SPR Model Application}

The 2D SPR model for the Karantinata beach is built by combining information from a DTM, a flood map for eastern storms with a return period of 100 years, a map of vegetation communities on the beach and results of manipulative experiments on these communities. The model is built following the methodology described in previous sections.

The landward boundary of the 2D SPR conceptual model is based on the flooded area for a current 1 in 100 year storm surge. The seaward boundary is assumed as starting from Mean Low Water Neaps. This allows the representation of any habitats within the inter-tidal zone.

The key approach for the 2D SPR is the combining of information on community vulnerabilities with flood mapping. The vulnerability of each community to flood duration was expressed in terms of a Critical Decomposition Time (CDT). The communities were mapped as individual polygons and each polygon was ranked by CDT into 4 groups by time of inundation - 24, 48, 72 and more than 72 hours of flood duration. Other floodplain elements are obtained from a DTM of the region. Fig 4 shows a land-use map of the region, showing the floodplain extent and elements for a 100 year return period storm surge. 


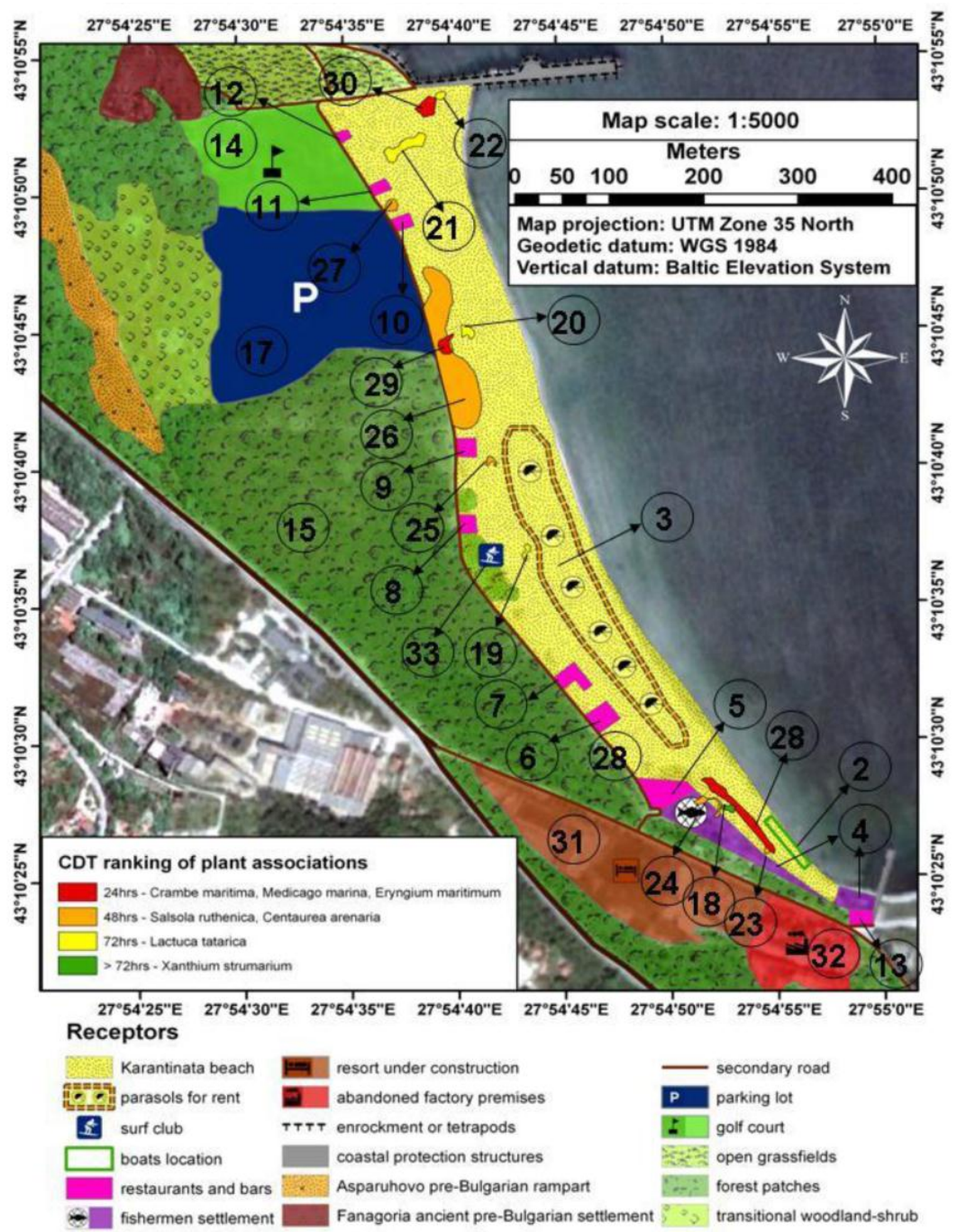

Figure 4: Floodplain extent (for 100 year storm event) and land-use map for Karantinata Beach 2D SPR indicating ranking of vegetation communities by CDT

The information on vegetation community vulnerabilities is combined with information from the land-use map in Fig 4 to provide the spatial distribution and spatial connectivity of the plant communities to other floodplain elements. Fig 5 shows the 2D SPR systems model for the study area. 

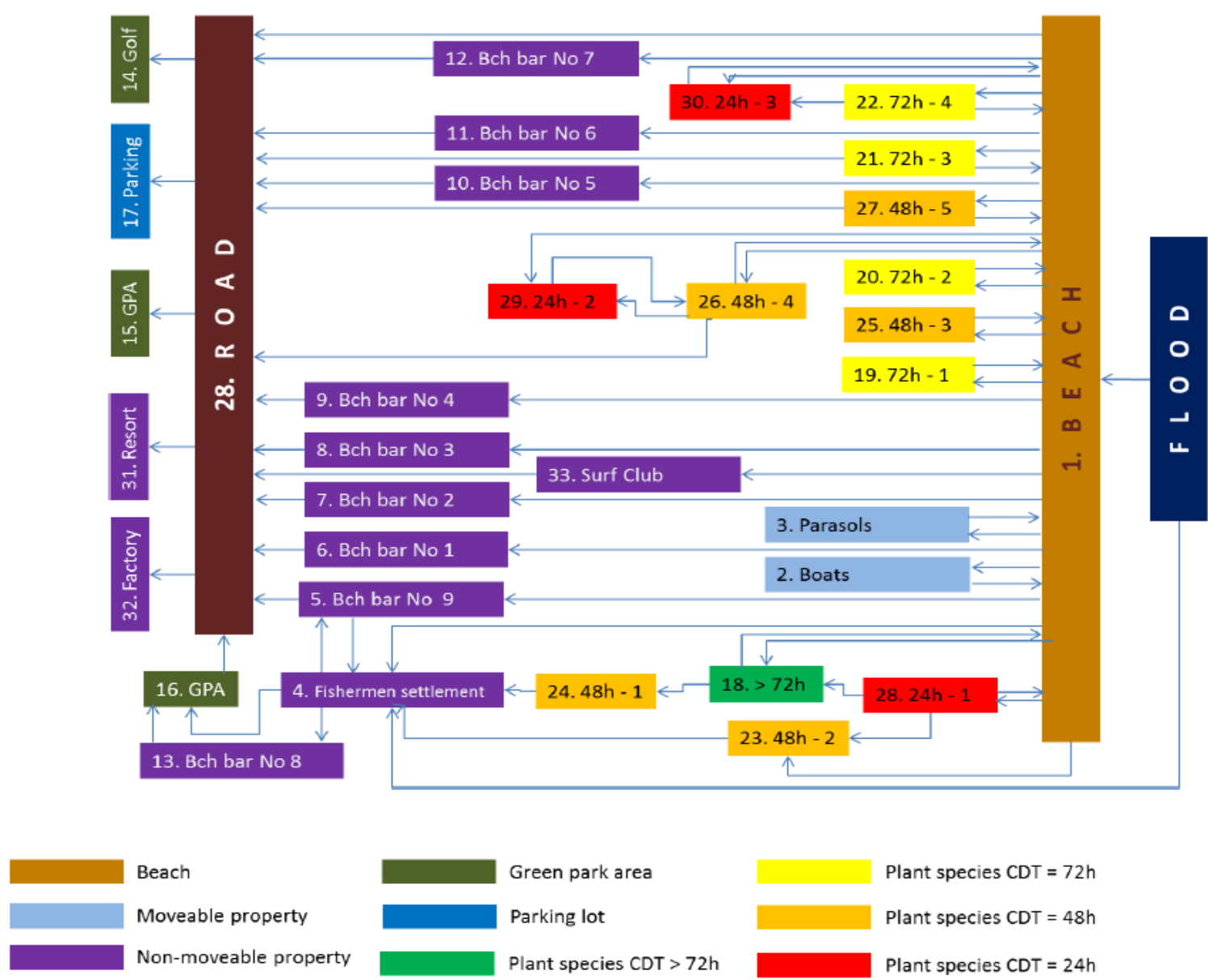

Figure 5: 2D SPR Conceptual Systems Model for Karantinata Beach indicating coastal habitats, vegetation communities, coastal settlements and infrastructure

\section{DISCUSSION}

The 2D SPR systems model in Fig 5 permits immediate recognition of the spatial relationships between coastal habitats and hinterland infrastructure. The case study shows that the conceptual model is an effective platform for integrating diverse kinds of information. In this case, the system diagram combines information on flood extents with information on vegetation community vulnerabilities. The approach helps structure and streamlines the inclusion of habitat characteristics within flood models by capturing essential and relevant information for flood risk assessments. The description of plant communities in terms of their vulnerabilities allows the representation of dynamic habitats within flood risk assessments - a change in habitat composition will be reflected by a change in CDT, while removal or addition of habitats can be represented by simple modification of existing 2D SPR. This offers a structured way of integrating habitats within coastal flood risk assessments. The 2D SPR can be quickly updated to reflect changes in relationships within the flood system, such as for instance, a removal of the habitats that will have an effect on the flood mitigation service provided to the beach during a storm. Additionally, the 2D SPR for the case-study provides immediate recognition of the vulnerability of floodplain elements on southern portion of the beach. In case of future spatial planning that provides for defending or adapting these settlements against flooding, the changes in connectivity can be easily and quickly represented within an updated 2D SPR.

Finally, the example shown provides a tool for extension to more quantitative probabilistic risk assessments. Since the 2D SPR is primarily a conceptual model, the links only indicate spatial connectivity of elements within the floodplain for flood propagation. However, the model can be easily modified to include additional information. For example the link from the beach (element 1) to the habitats (elements 18 to 29) may include information on the health of the beach and the corresponding vulnerability of the habitat. In this manner, changes to habitat vulnerabilities due to changes in the states of linked elements may be quantified and studied in further detail. 


\section{CONCLUSIONS}

Coastal habitats in Europe (and globally) are threatened ecosystems that require protection from damage due to human and natural forces. At the same time several of these habitats are recognised as providing valuable ecosystem services to human beings, including flood buffering and protection. However these habitats are largely overlooked within coastal flood risk assessments. The 2D SPR conceptual systems model presents a unique and structured framework for integrating coastal habitats and information on their ecological vulnerabilities and other floodplain elements with whom they share a spatial relationship. The 2D SPR model described in this study simultaneously provides a description of the ecological vulnerabilities of unique vegetation communities on the Bulgarian Black Sea Coast. This information is presented along with a description of their spatial connectivity to adjacent floodplain elements based on flood maps. The conceptual model provides an immediate recognition of the importance of coastal habitats in flood mitigation and captures inter-relationships between the habitats and other floodplain elements. The model provides a robust means of extension to more quantitative probabilistic assessments of changes in habitat state and vulnerability and the potential impact of changes to connected floodplain elements.

\section{ACKNOWLEDGEMENTS}

The support of the European Commission through the project "Innovative Technologies for safer European coasts in a changing climate" (THESEUS), Contract 244104, FP7.2009-1, www.theseusproject.eu, is gratefully acknowledged.

\section{REFERENCES}

Acreman M.C., Fisher J., Stratford C.J., Mould D.J. and Mountford J.O., 2007. Hydrological science and wetland restoration: some case-studies from Europe. Hydrology and Earth System Sciences, 11(1): 158-169.

Adger, W.N., Hughes, T.P., Folke, C., Carpenter, S.R. and Rockström, J., 2005. Social-ecological resilience to coastal disasters. Science, 309(5737): 1036-1039.

Airoldi, L. et al., 2005. An ecological perspective on the deployment and design of low-crested and other hard coastal defence structures. Coastal Engineering, 52(10-11): 1073-1087.

Airoldi, L. and Beck, M.W., 2007. Loss, status and trends for coastal marine habitats of Europe. In: R.N. Gibson, R.J.A. Atkinson and D.M. Gordon (Editors), Oceanography and marine biology: An annual review. CRC Press, Boca Raton, Florida, USA, pp. 345 - 405.

Alongi M.D., 2002. Present state and future of the world's mangrove forests. Environmental Conservation, 29: 331-349.

Danielsen, F. et al., 2005. The Asian tsunami: A protective role for coastal vegetation. Science, 310(5748): 643.

EC, 2004. Living with coastal erosion in Europe - sediment and space for sustainability, OPOCE, Luxembourg.

Edgar, G.J., Barrett, N.S., Graddon, D.J. and Last, P.R., 2000. The conservation significance of estuaries: A classification of tasmanian estuaries using ecological, physical and demographic attributes as a case study. Biological Conservation, 92(3): 383-397.

EEA, 2010a. 10 messages for 2010 - coastal ecosystems, EEA, Copehagen, Denmark.

EEA, 2010b. Ecosystem accounting and the cost of biodiversity losses: The case of coastal Mediterranean wetlands, EEA, Copenhagen, Denmark.

European Commission, 2007a. The Habitats Directive, Retrieved September 2012, from http://ec.europa.eu/environment/nature/legislation/habitatsdirective/index_en.htm. European Commission, 2007b. A new Floods Directive. Retrieved September 2012, from http://ec.europa.eu/environment/water/flood_risk/index.htm.

Evans, E. et al., 2004. Foresight future flooding: Scientific summary: Volume I - future risks and their drivers. Office of Science and Technology, London.

FLOODSite Consortium, 2009. Integrated flood risk analysis and management methodologies. Available at www.floodsite.net [Accessed: September, 2012]

Friess D.A., Spencer T., Smith G.M., Moller I., Brooks S.M. and Thomson A.G., 2012. Remote sensing of geomorphological and ecological change in response to saltmarsh managed realignment, The Wash, UK. International Journal of Applied Earth Observation and Geoinformation, 18: 57-68. King S and Lester J.N., 1995. The value of salt-marsh as a sea defence. Marine Pollution Bulletin, 30(3): 180-189. 
Lotze, H.K. et al., 2006. Depletion, degradation, and recovery potential of estuaries and coastal seas. Science, 312(5781): 1806-1809.

McFadden L., Spencer T., Nicholls R.J., 2007. Broad-scale modelling of coastal wetlands: what is required? Hydrobiologia 577: 5-15

Meyer D.L., Townsend E.C., Thayer G.W., 1997. Stabilisation and Erosion Control Value of Oyster Cultch for Intertidal Marsh. Restoration Ecology, 5(1): 93-99.

Moller, I, 2006. Quantifying saltmarsh vegetation and its effect on wave height dissipation: Results from a UK East coast saltmarsh. Estuarine, Coastal and Shelf Science, 69: 337-351.

Narayan, S. et al., 2012. A holistic model for coastal flooding using systems diagrams and the Source Pathway - Receptor (SPR) concept. Nat. Hazards Earth Syst. Sci, 12: 1431-1439.

Small, C. and Nicholls, R.J., 2003. A global analysis of human settlement in coastal zones.

Stancheva, M., Marinski, J., Peychev, V., Palazov, A. and Stanchev, H., 2011. Long-term coastal changes of Varna Bay caused by anthropogenic influence. Geo-Eco-Marina, 17(1): 33-40.

Suchanek, T.H., 1994. Temperate coastal marine communities: Biodiversity and threats. American Zoologist, 34(1): 100-114.

Tanaka N., Yasushi S., Mowjood M.I.M, Jinadasa K.B.S.N. and Homchuen S., 2007. Coastal vegetation structures and their function in tsunami protection: experience of the recent Indian Ocean tsunami. Landscape and Ecological Engineering, 3:33-45.

THESEUS Consortium, 2012a. A heavy storm hits the bulgarian coast. Retrieved September, 2012, from http://www.theseusproject.eu/index.php?option=com_content\&view=article\&id=54\%3Aa-heavystorm-hits-bulgarian-coast\&catid=12\%3Anewsletter-3\&Itemid=5.

THESEUS Consortium, 2012b. Theseus : Innovative technologies for safer European coasts in a changing climate (www.theseusproject.eu).

Vergiev, S., Filipova-Marinova, M., Trifonova, E., Kotsev, I., Pavlov, D. The effect of sea-water immersion on viability of the psamophilous species Leymus racemosus (Lam.) Tzvel. ssp. sabulosus (Bieb.) Tzvel and Ammophila arenaria (L.) Link. Comptes rendus de l'Academie bulgarie des Sciences (In press)

Vitousek, P.M., Mooney, H.A., Lubchenco, J. and Melillo, J.M., 1997. Human domination of Earth's ecosystems. Science, 277(5325): 494-499.

Wolfe S.A. and Nickling W.G., 1993. The protective role of sparse vegetation in wind erosion. Progress in Physical Geography, 17(1): 50-68.

Woodhouse W.W., Seneca Jr. E.D., Broome S.W., 1976. Propagation and Use of Spartina Alterniflora for Shoreline Erosion Abatement. USACE Coastal Engineering Research Chapter. Technical Report No. 76-2. Fort Belvoir, Virginia, USA. 